\title{
Fighting Poverty, Combatting Social Exclusion
}

\author{
William L. Partridge
}

The Chinese have a saying: through a drop of water you can see the whole ocean. This chapter analyzes the process of integrating social development policy and practice into the operations of the World Bank through the lens of my own personal experience, a drop of water through which we will see how sociologists and anthropologists transformed the larger organizational culture of the institution.

My work in the World Bank grew out of my research on the social and cultural impacts of involuntary resettlement. The filling of the reservoir of Mexico's Aleman Dam, constructed on the Papaloapan River in the mid-1950s, forced some 20,000 Mazatec indigenous people to abandon their homes and farms. They were provided new homes and farmlands in five different resettlement sites by the Government of Mexico. When I visited them in the mid-1970s four out of the five new settlements were complete failures. One was successful.

Prior to their resettlement, the Mazatec had been independent small-scale peasant farmers, marketing coffee, maize, sesame, and other cash crops to urban markets. But the inhabitants of the four failed settlements had been impoverished: they no longer farmed the replacement land that had been allocated to them, education and health conditions were dismal, and they had been reduced to wage labor on neighboring plantations and cattle estates. In contrast, the Mazatec in the successful settlement were producing surplus maize, plantain, mango, citrus, sugar cane, and other crops sufficient to permit investments/savings in the form of livestock. They enjoyed levels of income, education, and health significantly higher than those of neighboring communities that had not been resettled.

How can one explain the dramatically different outcomes? With support from the National Science Foundation (USA), this was the focus of my field research which continued through 1977-1978. Without my being aware of it, the published research results were read by staff of the World Bank, Inter-American Development Bank,

\footnotetext{
W. L. Partridge $(\bowtie)$

Vanderbilt University, Nashville, Tennessee, USA 
World Health Organization, Organization of American States and others. ${ }^{1}$ Those staff were aware that involuntary resettlement operations caused by hydroelectricity, irrigation, water supply, transport corridor, and other large-scale infrastructure projects were almost always failures, leaving the displaced people impoverished.

This was the opposite of what was supposed to be the purpose of a development investment in the first place. I began to receive requests to consult on resettlement operations in projects underway, to speak at seminars and training courses at headquarter offices, and to participate in the preparation of new projects. Throughout 1983, 1984, and 1985 my time was increasingly absorbed by consultancies for these multilateral government organizations, and I increasingly postponed academic pursuits to concentrate on practicing anthropology.

\section{Critic and Gadfly}

Two examples will illustrate what that work was like.

- In India the Maharashtra Composite Irrigation III project was underway, displacing and presumably resettling over 18,000 people from land flooded by the storage reservoir. The World Bank had received protests claiming that displaced farmers had not been resettled to new lands, but the Government of India claimed $90 \%$ had been provided land to replace the farms that had been flooded. I was sent to investigate. Not speaking Hindi or Marahrati, I recruited Professor L. K. Mahapatra (University of Orissa) who had studied resettlement disasters elsewhere in India and he agreed to assist me in a field survey of the affected villages. I paid his fees and expenses from my consulting earnings. We surveyed 13 of the 20 affected villages. We found that only $5 \%$ of farmers had received compensation sufficient to buy replacement land; fully $95 \%$ were made landless and impoverished. Back in Washington my report resulted in disciplinary measures for the team leader responsible for the preparation, appraisal, and supervision of the project. The World Bank department responsible requested that the Government of India take corrective measures to help the victims in regaining their lost lands, to which the Government of India responded by ignoring the request. By then the loan had been entirely disbursed and the World Bank staff

\footnotetext{
${ }^{1}$ Partridge, W. L., A. Brown, and J. Nugent (1982) The Papaloapan Dam and Resettlement Project: Human Ecology and Health Impacts. In Involuntary Migration and Resettlement. A. Hansen and A. Oliver-Smith (eds). pp. 245-263. Boulder, Colorado: Westview Press; Partridge, W. L. and A. Brown (1982). Agricultural Development Among the Mazatec: Lessons from Resettlement, Culture and Agriculture 16, pp. 1-9; Partridge, W. L. (1983) Desarrollo Agrícola Entre Los Mazatecos Reacomodados, American Indígena XLIII, 2, pp. 343-362; Partridge, W. L. (1984) "Relocalización en las Distintas Etapas de Desarrollo de los Emprendimientos Hidroeléctricos" en Efectos Sociales de las Grandes Represas en América Latina. F. Suárez, R. Franco, E. Cohen (eds). Buenos Aires: Organización de los Estados Americanos y Naciones Unidas. pp. 151-182.
} 
felt they had little leverage left to force the issue. The affected people were left impoverished. ${ }^{2}$

- The Inter-American Development Bank (IDB) contracted a comparative analysis of a successful resettlement project, the Arenal Hydroelectric Project resettlement in Costa Rica, and what they considered to be a failed resettlement operation, the Chixoy Hydroelectric Project in Guatemala, for the purpose of advising on establishing an IDB resettlement policy. After presenting my findings at an IDB seminar in Washington I was asked by the World Bank, which together with IDB had co-financed the Guatemala project, to present the analysis of the Chixoy experience to the staff of the department responsible for Guatemala. The presentation reported the human disaster that was resettlement at Chixoy: two years after the reservoir filled I found 3700 Maya huddled in temporary shacks just above the reservoir margin, their corn fields, fruit trees, and pastures under water, surviving by selling off their livestock, with no schools, no potable water, no roads. The World Bank team responsible had not once visited the resettlement operation, and the unfolding disaster was never mentioned in the team's supervision reports to management over the previous 4 years. The World Bank project team in attendance was incensed; they angrily defended themselves and attacked me. At that point a man stood up in the rear of the room, who turned out to be the Vice President for the Latin America and the Caribbean Region, and said: "What we have here is a fuck up, and I want it fixed." He then left the room. The fix turned out to be holding up a new loan to the Government of Guatemala until they signed a legal agreement incorporating a resettlement plan designed to restore the lands, production systems, and livelihoods of the affected Maya. I was asked to help prepare and appraise the new plan in the following months. ${ }^{3}$

These and other consultancies convinced me that one could practice anthropology in the World Bank, that there was need and scope for making positive contributions, and that there were managers and staff willing to use empirical findings to make better decisions. In 1986 I was invited to work as a full-time consultant by the World Bank's Social Policy Adviser, Michael M. Cernea, a sociologist from Romania and the first non-economist social scientist hired by the World Bank. It was a one- year contract, but I accepted without hesitation, resigned as Chair of the Anthropology Department at Georgia State University, and with my family's support moved to Washington DC.

\footnotetext{
${ }^{2}$ Professor Mahapatra and other social scientists in India with support from colleagues in the multilateral governmental organizations continued working to influence governments at the national, state, and local level to assist these displaced people and others in other similar projects to regain their lost livelihoods.

${ }^{3}$ While the Guatemalan Electricity Institute that owned the Chixoy project agreed to the new plan at the time of appraisal, the lawyer for the government succeeded in excluding any mention of it in the legal agreement for the new loan. The Government of Guatemala consequently ignored the agreement entirely. See Partridge, W.L. (2006). "The Guatemala Chixoy Project Resettlement Disaster," presented to the American Association for the Advancement of Science workshop on Reparations and Resettlement. American School of Social Research, Santa Fe, New Mexico.
} 
The following year when the World Bank created its first Environment Divisions in each of its Regional Vice Presidencies I was offered and accepted a permanent staff position as Anthropologist in the newly-formed Environment Division for the Asia and Pacific Region. I learned soon that working within the institution would be unlike what I had experienced as an external consultant.

\section{Staff Member}

My anthropological training had been in Latin American, I was fluent in Spanish, and had 15 years of research experience in Latin America. So it may seem a bit odd that I would be hired by the World Bank initially in the Asia and Pacific Region. What that tells you is that the Bank hired me not because I was a cultural or regional expert but because I could help them solve a problem. That problem was most pressing in the Asia and Pacific Region, where there were many ongoing resettlement operations, all of them failing, and many more in the pipeline. World Bank management could care less if I was an anthropologist or a Martianwhat they wanted was someone who could help member governments come up with workable resettlement plans.

My role had changed from being a gadfly and critic of World Bank management and staff actions or omissions, independent and not responsible for decision making, to a member of the staff responsible for making decisions. Now I was to work directly with the engineers, lawyers, and other civil servants of member governments-Ministries of Public Works, Secretariats of Agriculture, Electricity Corporations, Departments of Irrigation-to correct past errors and avoid future ones. In that role I was to confront opposition from my government counterparts ranging from polite indifference to undisguised hostility. Many viewed forced resettlement as a kind of "collateral damage" that was an unavoidable cost of development and, moreover, the exclusive provenience of government. And opposition from government counterparts translated into opposition from some World Bank staff, many of whom resented having to share scarce Bank budgets historically monopolized by economists, engineers, financial analysts, etc. with anthropologists, environmental scientists, and other "new guys on the block."

To be viable, an involuntary resettlement operation must fit a country's legal, regulatory, and policy framework, specifically, the statues governing land acquisition, compensation, and resettlement. My anthropological training had not prepared me for legal research. Some of my greatest allies were found in the World Bank's legal department. They guided me to the relevant statutes in India, Indonesia, Nepal, Philippines, China, etc. Reading them became my nightly homework.

I quickly learned that the majority of countries legal frameworks for land acquisition, the major cause of involuntary resettlement, are entirely silent on the 
resettlement and re-establishment of displaced people. ${ }^{4}$ Yet member countries and the World Bank staff must comply with the World Bank's operations policy on involuntary resettlement issued by its Board of Executive Directors, representing all member countries. ${ }^{5}$ That operations policy explicitly requires (1) avoidance or minimization of resettlement where possible and (2) where resettlement cannot be avoided, the formulation and implementation of a resettlement plan designed to improve, or at least restore to pre-project levels, the livelihoods and standards of living of people displaced by the project. Thus major portions of my work became helping draft and negotiate resettlement policy frameworks and plans-their designs, staffing, and financing-to socioeconomically re-establish affected people.

\section{Opportunities Discovered}

Much of my work was shuttling between projects, sometimes alone but usually as part of a World Bank team, to supervise, prepare, appraise, and monitor and evaluate resettlement operations. I was in the field about 200 days a year. Most countries in which I worked had well-developed faculties of anthropology, and I made it a priority to recruit in-country colleagues to work with me. Typically I would disappear for a week or two into the villages affected by a project, accompanied by my in-country anthropological colleagues, while my fellow team members remained in the capital city conversing with government officials. Consequently, my findings from the field often did not match the information conveyed to my colleagues by our government counterparts. And this usually meant rather tense meetings in the capital city and back at headquarters. With the support of World Bank management, and sometimes despite resistance from Bank staff, the result was the first generation of solid resettlement and re-establishment plans incorporated into projects and, most importantly, into legal agreements between the Bank and its borrowers. ${ }^{6}$

\footnotetext{
${ }^{4}$ Shihata, Ibrahim F. I. (2000). "Involuntary Resettlement in World Bank Financed Projects." In The World Bank in a Changing World: Selected Essays by I.F.I Shihata, Vice President and General Counsel, The World Bank. Dordrecht/Boston/London: Martinus Nijhoff Publishers.

${ }^{5}$ World Bank (1980). Operational Manual Statement 4.30: Involuntary Resettlement. Washington DC; World Bank (1990) Operational Directive 4.30: Involuntary Resettlement. Washington DC; World Bank ( 2001) Operations Policy 4.12: Involuntary Resettlement. Washington DC.

${ }^{6}$ Forced resettlement is always perceived as a disaster by displaced people. But human communities are not homogeneous and neither are their responses to disaster. Generally the elite take their compensation money and leave, rather than be subjects of a government resettlement program. At the other end of the spectrum, some of the most vulnerable will fail for lack of capacity to take advantage of the investments in resettlement programs. Most others, however, often discover a silver lining in the disaster. The effect of the exit of corrupt elites-large landowners, commercial middlemen, shopkeepers, money lenders-is like taking the lid off a boiling pot. The capable, hardworking majority are liberated to make the most of new opportunities represented by the resettlement investments, opportunities that previously would have been captured entirely by the corrupt elite. See Partridge, W. L. (1989) "Involuntary Resettlement in Development Projects: Text
} 
Equally important was contributing to the operationalization of the World Bank's resettlement policy. Michael Cernea was the principal author of the Bank's operations policy on involuntary resettlement issued by the Board of Executive Directors. ${ }^{7}$ While the policy was explicit regarding the risks of impoverishment and the overarching objective of involuntary resettlement operations to restore lost production systems, housing, infrastructure, etc. to avoid impoverishment, it was less explicit regarding how to achieve those objectives. One of my first assignments, therefore, was to design and write up guidelines of what steps World Bank staff and governments should take to comply with the policy, what were the component elements of a workable resettlement plan, and what actions were required to achieve the policy objectives. That guideline was included as an Annex to Cernea's landmark Involuntary Resettlement in Development Projects: Policy Guidelines in World BankFinanced Projects. ${ }^{8}$ Its basic message was: because forced resettlement destroys a previous way of life, all resettlement operations must be designed and appraised as development projects. This and other technical materials we produced became the basis for a series of training seminars and workshops for Bank staff, managers, and consultants in the coming years. The feedback from staff and consultants regarding accumulating experience was an ongoing learning process that contributed to our refinement of the policy and its reissuance by the Board in 1990 and again in 2001.

An additional responsibility was identifying and recruiting anthropologists from the member countries of the World Bank who could strengthen our capacity. When I was appointed Environmental Assessment Manager and later Chief of the Environment and Social Development Unit of the Latin America and Caribbean Region most of my staff were Greek, British, and US nationals. Few spoke Spanish or Portuguese and most knew little of the societies where they were working. There existed in the World Bank the belief that staff should not work in their own countries or region in order to remain "objective." I believed the opposite- to be effective one had to know the society, its language, and system of governance. So I began to hire high caliber Latin American professionals, eventually assembling a team of 23 sociologists, anthropologists, environmental engineers, biologists, ecologists, and economists from Brazil, Colombia, Ecuador, Costa Rica, Chile, and so forth.

Finally, a fourth area of activity was reviewing proposed World Bank loans to ensure that they were in compliance with the institution's involuntary resettlement, environmental assessment, and indigenous peoples policies. When the Board of Directors created the environment and social development units in each Regional Vice Presidency, it also instituted a process of mandatory screening and technical

of the First Annual Elizabeth Colson Lecture, Oxford University, 8th of March 1989.” Journal of Refugee Studies 2:3:373-384.

${ }^{7}$ Cernea was assisted by anthropologists Thayer Scudder (California Institute of Technology) who had studied the disastrous Kariba Dam resettlement and David Butcher (Edinburgh University) who had documented the equally tragic Akosombo Dam resettlement in drafting the policy statement.

${ }^{8}$ Cernea, Michael (1988). Involuntary Resettlement in Development Projects: Policy Guidelines in World Bank-Financed Projects. World Bank Technical Paper Number 80. Washington, DC: World Bank. 
review by environmental and social specialists of future lending operations. This gave our small Environment and Social Development Unit unprecedented influence in decision making. More than once we found project preparation to be incompleteinstitutional capacities weak, technical designs questionable or absent, social impacts denied or ignored, financial management systems nonexistent - or even in violation of World Bank social and environmental policies. More than once World Bank management backed us up and sent the project back to the drawing boards. Such review responsibility also represented a tremendous work load for the few environmental and social specialists then employed, and fueled our recruitment of more. In the space of 5 years the number of environmental and social scientists in the Bank grew from a handful to more than 200 professionals.

\section{New Challenges}

The Environment and Social Development Unit's responsibilities extended considerably beyond involuntary resettlement. We provided the experience and expertise to ensure that a formal Environmental Assessment (EA) was carried out for all projects that entailed significant social and/or environmental impacts. ${ }^{9}$ A core element of the EA process is prior and informed consultation with and participation of stakeholders likely to be affected and, especially, local communities that would suffer direct or indirect negative impacts. ${ }^{10}$

In that regard a particularly difficult and sensitive challenge was prior and informed consultation with indigenous populations of the Americas, who were structurally excluded from the dominant societies due to ubiquitous language, culture, and race discrimination. Consultation with indigenous peoples, much less their participation in EA's, or participation in development projects of any kind, was unprecedented in Latin America and the Caribbean. Only Canada and Mexico had evolved mechanisms, instruments, and processes, albeit, incomplete and flawed, for including to any extent indigenous peoples in the development process. Throughout the rest of the Americas indigenous peoples remained voiceless, invisible, isolated, and impoverished.

While we began by insisting on consultation and participation in the EA process our larger agenda quickly moved to involving indigenous communities in the design, staffing, implementation, and monitoring and evaluation of all development projects affecting their territories, natural resources, and cultures. The pushback was strong and immediate. World Bank staff were well aware that borrower governments of the region almost always represented only the dominant and profoundly racist segments

\footnotetext{
${ }^{9}$ World Bank (1991). Operational Directive 4.01 Environmental Assessment. Washington, DC.

${ }^{10}$ Partridge, W.L. (1994). "People's Participation in Environmental Assessment in Latin America: Best Practices," LATEN Dissemination Note Number 11, Latin America and Caribbean Technical Department. Washington, DC: World Bank.
} 
of their societies, and they did not relish attempts to redress this deeply rooted inequity.

We had three powerful allies in the struggle to direct Bank investment towards indigenous communities. First, in the 1990s the indigenous communities themselves were rising up to demand their right to "development with identity." ${ }^{11}$ In some cases they achieved voice and representation peacefully (Ecuador), in others their efforts were violently repressed (Guatemala). But the tide could not be turned back.

Second, the international community, including the United Nations and human rights non-governmental organizations mobilized in support of the indigenous movements. We were able to secure a major grant from the Swedish International Development Agency to conduct consultations with indigenous organizations. We used it to finance a series of workshops with indigenous communities (costs of travel, lodging, meals for indigenous leaders and in-country anthropologists) in eleven countries of the region. In these workshops we invited them to propose development projects for their communities and we promised to put those proposals on the table with their governments. We followed up with further visits by international and in-country anthropologists to help them formulate their proposals in forms and formats the World Bank could act upon.

Finally, our indigenous development initiative was strongly endorsed by the Regional Vice President for Latin America and the Caribbean, Shahid Javed Burki of Pakistan, and his Chief Operations Adviser, Myrna Alexander of Canada. Without this high-level support and the efforts of in-country anthropologists we would not have been able to overcome the resistance both within the World Bank and in member governments. Within two years we shepherded through the first generation of World Bank loans to indigenous organizations in Ecuador, Mexico, Argentina, Guatemala, and Peru. Recognizing the significance of this initiative, the Vice President then made the decision to hire a sociologist or anthropologist in each of the resident offices of the World Bank throughout the region to help target World Bank investments to benefit the structurally excluded: the afro-descendants, the indigenous, ethnic minorities, and other communities trapped in the informal sector of a country's economy.

\footnotetext{
${ }^{11}$ Partridge, W. L. (1990). “The Fate of Indigenous People: Consultation and Coordination Can Avoid Conflict”, The Environmental Forum 7:5: pp. 29-30. Partridge, W.L. and S. H. Davis (1994). Promoting Indigenous Peoples Development in Latin America, Finance and Development, March, pp. 38-41. Partridge, W. L., J. Uquillas Rodas and K. Johns (1998). "Including the ExcludedEthnodevelopment in Latin America". Poverty and Inequality: Proceedings of the Annual World Bank Conference on Development in Latin America and the Caribbean 1996, Bogotá Colombia. pp. 229-250. Washington, DC: World Bank.
} 


\section{Final Reflections}

Practicing anthropologists bring to multilateral government organizations like the World Bank the capacity to analyze the myriad stakeholders, countervailing forces and vested interests of society which perpetuate the structural obstacles that exclude the poor and vulnerable. But analysis is merely the first step. Overcoming such obstacles always entails going beyond the normal functioning of government institutions. It is not that government institutions do not function well, but that they do so only for their clients. The excluded are not and have never been their clients. Reaching the poor and those at risk of impoverishment entails designing innovative mechanisms, processes, and instruments that permit the flow of services, goods, and works to those who have never had access to development resources. It means going beyond business as usual to challenge and correct the institutionalized social exclusion that perpetuates persistent poverty.

Practicing anthropologists in multilateral government organizations like the World Bank depend upon empirical field investigation. It is only through in vivo field investigation that the institutionalized structural obstacles that perpetuate poverty in any given society can be recognized and addressed. While anthropologists on the staff of such organizations do not conduct lengthy ethnographic research, they identify, recruit, and commission in-country anthropologists who have conducted in-depth investigation, who are familiar with the languages and cultures of their societies, and who manifest an ethical commitment to people's participation in the development decisions that will affect their lives. The latter have the requisite knowledge and skills to tailor development interventions to defeat structural social exclusion, and the former have the job of involving them and making it stick.

William Partridge recently retired from Vanderbilt University where he was Professor of Anthropology and Professor of Human and Organizational Development. From 1986 to 2001 he worked for the World Bank in Washington, DC and Buenos Aires, Argentina. He is author of Guidance Note for Socio-Cultural Analysis (with M. C. Mejia), Washington, DC: Inter-American Development Bank (2012); Social Analysis Sourcebook (with A. Dani, T. Dichter, K. Kuehnast, A. Kudat, B. Bulent Ozbilgin, M. Mejía), Washington, DC: World Bank (2002); Reasentamiento en Colombia (edited). Bogota and Washington DC: United Nations High Comissioner for Refugees, World Bank, Corporacion Antioquia Presente, and Office of the President, Government of Colombia (2000); "Successful Involuntary Resettlement: Lessons from the Costa Rica Arenal Project". In M. Cernea and S. Guggenheim (editors). Anthropological Approaches to Resettlement. Boulder, Colorado: Westview Press, pp. 351-374 (1993); The Human Ecology of Tropical Land Settlement in Latin America (edited with D. Schumann). Boulder, Colorado: Westview Press (1989); and Applied Anthropology in America: Revised Second Edition (edited with E. Eddy), New York: Columbia University Press (1987). Partridge received his PhD in Anthropology from the University of Florida. 
Open Access This chapter is licensed under the terms of the Creative Commons Attribution 4.0 International License (http://creativecommons.org/licenses/by/4.0/), which permits use, sharing, adaptation, distribution and reproduction in any medium or format, as long as you give appropriate credit to the original author(s) and the source, provide a link to the Creative Commons license and indicate if changes were made.

The images or other third party material in this chapter are included in the chapter's Creative Commons license, unless indicated otherwise in a credit line to the material. If material is not included in the chapter's Creative Commons license and your intended use is not permitted by statutory regulation or exceeds the permitted use, you will need to obtain permission directly from the copyright holder. 